\title{
Investigation and Analysis of Wind Turbines Optimal Locations and Performance in Iraq
}

Bashaer Mohammed

Research Associate University of Baghdad Department of Energy Engineering Iraq

Oday Ibraheem Abdullah

Assist. Prof. Dr.-Ing University of Baghdad Department of Energy Engineering

Amani I. Al-Tmimi Assist. Prof. Dr. Al-Mustansiriyah University Department of Atmospheric Sciences
Wind energy is one of the most important types of renewable energy resources in the world. The wind energy is considered friendly to the environment and relatively inexpensive power. These advantages are considered the main reasons to select wind turbines to produce the electricity in the world. An accurate analysis of the wind data is considered the main key to select the optimal location and the suitable wind turbine based on the estimated power and cost. In this research paper, a new program was built and then developed based on MATLAB to analyze deeply the wind energy in the selected locations in Iraq. MATLAB Graphical User Interface (GUI) was used to present the developed program of "WIND ENERGY ANALYSIS". This software has the ability to analyze the wind speed, processing the missing data and find the correlation coefficients, besides plot the results of this analyis (wind and Rose). Furthermore, the software presented the full details about the parameters of the Weibull distribution based on two different methods (Standard Deviation Method and Energy Pattern Factor) in order to select the optimal wind turbine in the specific site depending on the minimum cost per $\mathrm{kWh}$ or maximum capacity factor generated from the wind energy system.

Keywords: Wind Power density, Weibull distribution, economic cost, Matlab (GUI).

\section{INTRODUCTION}

After the industrial revolution in the 1970s of last century and the widely using of fossil energy resources that affected negatively the environment which led to appearing some undesired phenomena such as global warming, desertification, drought, melting of ice and other signs of climate change. Therefore, the necessary need for alternative sources of renewable energy those have less negative effect on the environmental. There are many types of the renewable energy resources such as solar, wind, hydro, geothermal, biomass and ocean thermal power. It can be considered that the wind energy is one of the most important resources to obtain the electricity. It is widely used in many countries especially in Europe. The potential energy of wind turbines can be calculated by raising the energy corresponding to possible wind speeds during the specific period of time. Therefore, the distribution of wind speed frequency plays a critical role to predict the output energy of the energy conversion system. Also, the probability distribution of the wind speeds variation in the region considered an important element to achieve the calculations.

During the last two decades, great attentions were

Received: December 2018, Accepted: October 2019 Correspondence to: Assist. Prof. Dr Oday I. Abdullah Department of Engineering, University of Baghdad, Baghdad-Aljadria 47024, Iraq

E-mail: oday.abdullah@tuhh.de paid towards the development of the statistical models to analyze the wind speed frequency distribution.

As seen from the literature, high concentration has been applied to analyze the wind using the Weibull function, because it's a suitable tool to analyze the wind speed data at the surface and the upper air [1].

In the literature review, there are several criteria have been presented to select the type of wind turbine that is most suitable for a specific site. One of the most popular one which developed by Jangamshetti and Rau, that achieved based on identifying of the optimum wind turbine performance index curve and gained from the wind turbine normalized power curves. It was found that higher energy production can obtained at the higher capacity factor [2].

There are many researchers who studied and analyzed the wind data using different methods. Rehman and Ahmad [3] analyzed the wind data for five coastal locations.

Rocha et al. [4] presented the analysis and comparison of seven numerical methods to find the parameters for Weibull probability distribution. Jowder [5] developed the statistical model for wind speed and power at various heights [5]. El Shimy [6] studied the problem of site matching of wind turbine generator using the improved formulation of the capacity factor. Huang and Wan [7] determined the modular approach to enhance the capacity factor computation of wind turbine generators. Albadi and El-Saadany [8] proposed a new method to estimate the capacity factor of the wind turbines based on the variable speed. 
There are many studies of wind turbine performance characteristics have been validated based on the modelling approaches [9-11]. The majority of these studies contextualize the models within the framework of classical wind resource locations, i.e. wind farms.

In Iraq, there are many evidences that confirm existence of the serious pollution in the environment such as increasing the temperature and dust storms [12]. Therefore, it should be to think critically to use the renewable energy widely to reduce this pollution. There are many researchers studied practically the wind energy in Iraq, started from the 1980s (Al-Assawi \& Zaki, 1986 [13]), they estimated the wind power potential in Iraq using monthly wind speed. Al-Tmimi [14] in 2007 investigated the wind potential using Weibull distribution and feasibility of installing the wind turbines in 19 stations in different sites of Iraq. The results presented the wind characteristics and assessment of the wind power in the selected sites. The results proved that in Iraq there is more than one promising site where the wind turbine can be installed and get energy from it economically.

In this paper, the solution of the coupling problem between the selection of location and type of wind turbine based on techno-economic criterion has been introduced. This analysis is considered an essential element before the installation of wind energy system in any country. This approach contains the accurate processes to select the optimum location and wind turbine for proposed locations depending on the minimum cost of kWh generated from wind energy system. The steps to achieve the developed approach are consumed time and effort to obtain the results based on the optimization processes. Therefore, it was proposed "WIND ENERGY ANALYSIS" software to achieve these calculations in easy way for users. The new software can be applied in any region (site) of the world because it has the flexibility to change the economic calculations according to any location of any country. Also, it has the potential to address a very large number of data for wind and turbines.

There are many researchers investigated the problems of the wind energy in order to find the optimal solutions by using various theoretical approaches [15-19].

\section{MATHEMATICAL FORMULATIONS OF WIND POWER}

This section presents the complete mathematical formulations to determine the wind power density that used to measure the capacity of wind resources in specified site. It can be found that the wind power density using the following formula [20],

$$
W P D=\frac{1}{2} \rho V^{3}
$$

where $\rho\left(\mathrm{kg} / \mathrm{m}^{3}\right)$ is the density and $V(\mathrm{~m} / \mathrm{s})$ is the wind speed. The wind power density based on Weibull distribution can be calculated by [20],

$$
W P D_{w}=\frac{1}{2} \rho c^{3} \Gamma\left(1+\frac{3}{k}\right)
$$

It can get the intensity of wind energy (WED) by multiplying the power by times as the following [21],

$$
W E D=W P D^{*} T
$$

The Weibull distribution can be characterized using the probability density function $(P D F)$ and the cumulative distribution function $(C D F)$ as follows [22],

$$
\begin{gathered}
f(U)=\frac{k}{c}\left(\frac{U}{c}\right)^{k-1} \exp \left(-\left(\frac{U}{c}\right)^{k}\right) \\
F(U)=\int_{0}^{U} f(U) d U \\
F(U)=1-e^{-\left(\frac{U}{c}\right)^{k}}
\end{gathered}
$$

where,

$$
F(U) \geq 0, U \geq 0 ; k>0, c>0
$$

There are more than seven methods to calculate the Weibull parameters [4] such as the Standard Deviation Method $(S D M)$. In this work, the Standard Deviation Method $(S D M)$ was used to find the Weibull parameters. The forms of the Standard Deviation Method $(S D M)$ are [21]:

$$
\begin{aligned}
k & =\left(\frac{S . D}{U m}\right)^{-1.086} \\
U m & =c \Gamma\left(1+\frac{1}{k}\right)
\end{aligned}
$$

The ratio of the total power available in the wind to the power corresponding to the mean wind speed is called the Energy pattern factor method $\left(E_{p f}\right)$ [23],

$$
E_{p f}=\frac{1 / n \sum_{i=1}^{n} U_{i}^{2}}{\left(1 / n \sum_{i=1}^{n} U_{i}\right)^{2}}
$$

where,

$$
k=3.957 E_{p f}^{-0.898}
$$

Usually, the data of wind speed are available in most cases on a height of $10 \mathrm{~m}$ above the ground level. Since the wind speed tends to increase with height in most locations. The height of the hub in the energy generation systems is more than $10 \mathrm{~m}$, therefore it's necessary to estimate the wind speed at the range of elevations that corresponding with the wind turbine which possible to install in the selected site. In order to transfer the anemometer height to the standard level or other desired heights, it should be used the power law equation as follows [24, 25].

$$
U_{2}=U_{1}\left(\frac{z_{2}}{z_{1}}\right)^{\alpha}
$$

The scale factor $c$ and form factor $k$ of the Weibull distribution will change as a function of height as the following expressions [26], 


$$
\begin{gathered}
c(h)=c_{o}\left(\frac{h}{h_{o}}\right)^{\alpha} \\
k(h)=k\left(h_{o}\right)\left[\frac{1-0.088 \ln \left(\frac{h_{o}}{10}\right)}{1-0.088 \ln \left(\frac{h}{10}\right)}\right] \\
n=\frac{\left[0.37-0.088 \ln \left(c\left(h_{o}\right)\right)\right]}{\left[1-0.088 \ln \left(\frac{h}{10}\right)\right]}
\end{gathered}
$$

\section{PERFORMANCE CHARACTERIZATION OF WIND TURBINE}

The performance of the wind turbine can be described based on the power curve; this curve represents the output of the electric power as a function of the hub height and wind speed.

Based on this curve, it can be predicted the power output of wind turbine and the energy production without knowledge the details of the turbine and its components [27]. In this study, it was selected two types of wind turbines (ATB Riva calzoni 500kw and Enercon3 $500 \mathrm{kw}$ ) which fit with the average wind speed of selected sites. Figure 1 shows the power curve of the wind turbine (Enercon3 500kw).

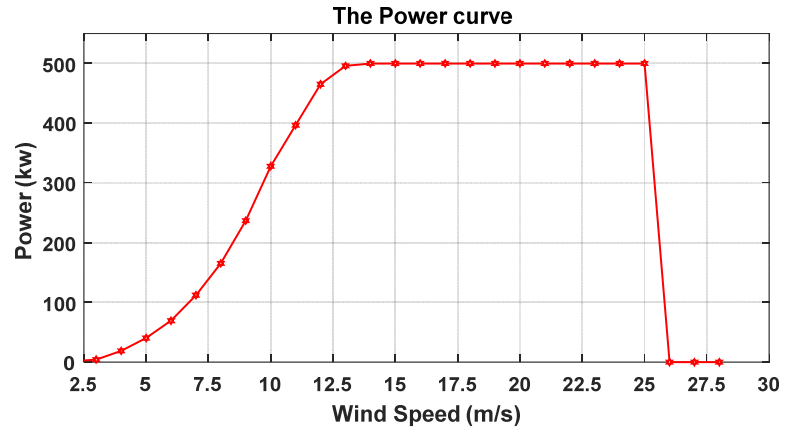

Figure 1. Wind turbine power curve (Enercon 3-500KW)

There are three key points on this curve: (1) cut-in speed $(2.5 \mathrm{~m} / \mathrm{s})$ where the turbine will not produce power; (2) rated speed $(12 \mathrm{~m} / \mathrm{s})$ at this rated power the wind turbine is produce the power; and (3) cut-off speed $(25 \mathrm{~m} / \mathrm{s})$ beyond this value, the wind turbine is not allowed to deliver power.

The annual energy production (AEP) can be calculated using the probability density function and the power curve of the selected wind turbines, it was calculated in hours by multiplying it by the value (8760) [14].

The capacity factor $(C F)$ is the ratio of the annual energy generated to the energy produced by the wind turbine during the rated power during the same period. The capacity factor is calculated as [28],

$$
C F=\frac{A E P}{\text { Rated output } * 8760}
$$

The power coefficient $(c p)$ is a significant parameter that represents the aerodynamic efficiency of wind turbines to convert the kinetic energy in the wind to the electrical power [29],

$$
c p=\frac{p}{\frac{1}{2} \rho A U^{2}}
$$

The cost per $k W h$ of wind turbine that generated electricity is the essential financial calculation to invest in the wind energy. In the present work, the simple form of the cost estimation will present to find the total cost of the electrical powers per unit time. The details that needed to find the cost of the electrical power are: the installation, running cost of the turbine and the lifetime of the wind turbine. It can be used the following formula to obtain the total cost [29],

$$
\text { Cost } / k w h=\frac{\text { Turbine \&other } \cos t+(\text { Annual recurent } \cos t s+\text { lifetime })}{A E P^{*} \text { Lifetime }}(
$$

\section{WIND ANALYSIS DATA USING MATLAB GUI}

A graphical user interface based on Matlab software [30] was built from scratch to find the optimal site and type of wind turbine. This research paper will present the first version of "WIND ENERGY ANALYSIS" software. This software consists of the main menu with windows to present the results as a plot in addition to the possibility to obtain or print the results in Excel sheet. The environment of this software is very friendly for users; therefore the users need short time to learn the tools and facilities of the software.

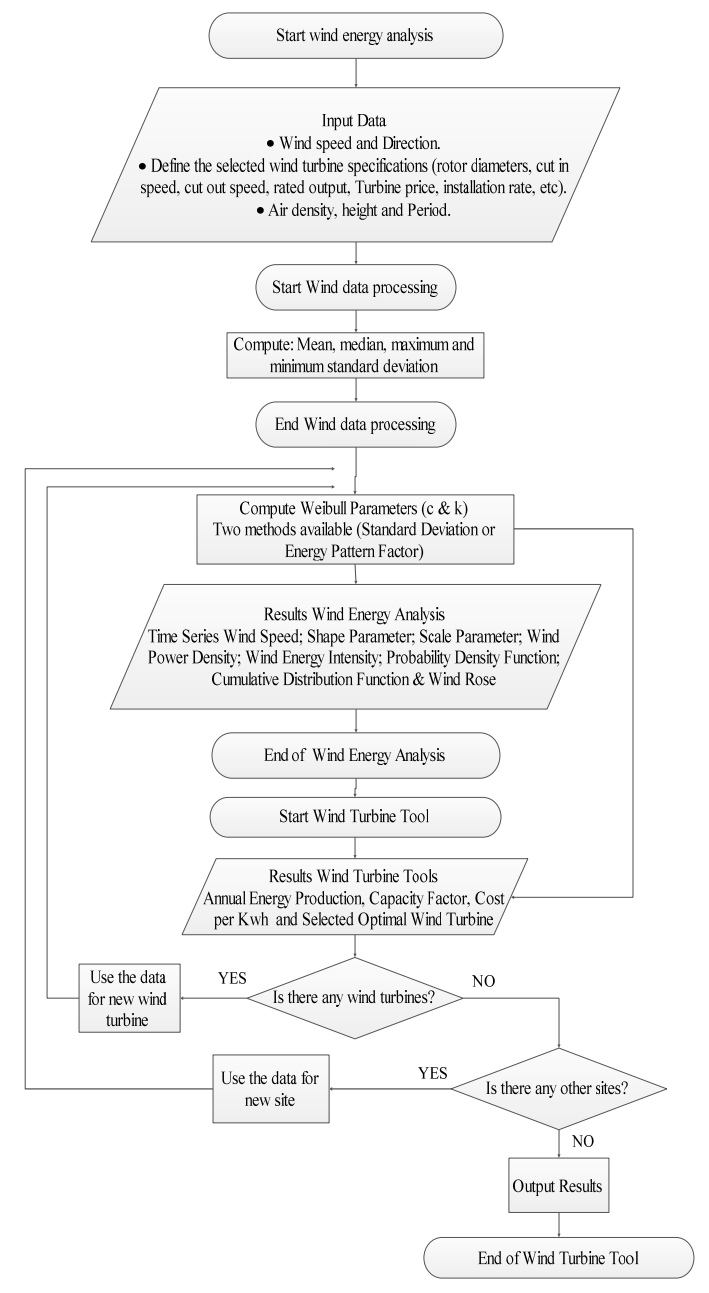

Figure 2. Flowchart of the "WIND ENERGY ANALYSIS" software 
The wind speed was investigated in different sites in Iraq to find the optimal location to install the wind turbine, in addition to studying the performance of wind turbines and selecting the optimum one based on the power and cost estimations. The help contains the details of all equations and definitions of the factors and constants that used in this software to help and guide the users to understand the theoretical approach that used to build the software. Figure 2 shows the flowchart of the "WIND ENERGY ANALYSIS" software.

\section{SITES AND OBSERVATIONS}

The data collected and used in this study were based on the daily average of wind speed at $10 \mathrm{~m}$ high above the ground level during the period of (2016-2017). These data were obtained from Iraq meteorological organization and seismology distributed in different locations in Iraq. The results of this paper focused on the most suitable sites in Iraq. Figure 3 illustrates the wind speed at selected stations in Iraq. The stations located in the south of Iraq are Amara, Basra, Al-Hay and Nasiriyah stations at the locations: longitude $(47.10,43.34,46.02$ and 46.14), and latitude (31.50, 32.23, 32.08 and 31.01), respectively. These stations are almost characterized as a flat topography with few roughnesses based on the previous studied (Figure 3 ).

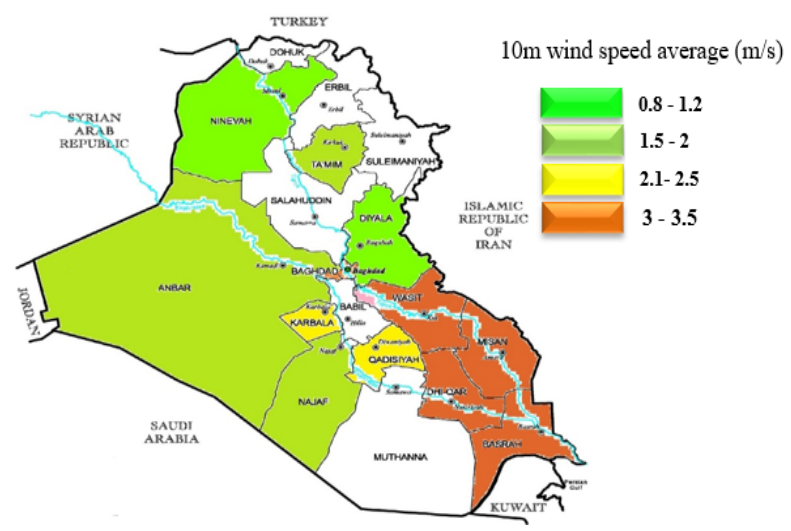

Figure 3. Map of wind speed at selected stations in Iraq

\section{RESULTS AND DISCUSSIONS}

This section presents the results of wind analysis in Amara, Basra, Al-Hay and Nasiriyah stations, and the optimal wind turbine that was possible to install in these sites using "WIND ENERGY ANALYSIS" software. The selection of wind turbine was based on the minimum cost per $k W h$ or maximum capacity factor generated from wind energy system. But before started with this step, a verification case study was done to show the reliability and accuracy of "WIND ENERGY ANALYSIS" software.

It can be seen from Figure 4 that the Homepage of MATLAB GUI software is called "WIND ENERGY ANALYSIS" and the types of the results that can be obtained using this software based on the data of "Basra station". A message about the data status will appear if it doesn't contain any missing data. Otherwise, if it contains any missing data it will be processed and given the correlation coefficient of statistical properties.
Table 1 lists the results of all statistical properties $\left(U_{m}, D, k, W P D\right.$ and $\left.W E I\right)$ using "WIND ENERGY ANALYSIS" software based on Weibull standard deviation method.

The monthly shape parameter $(k)$ which indicates variability or stability of the wind speed, where the range of $k$ is $(k \leq 1.5)$ correspond to highly variable or gusty winds, whereas $(1.5<k \leq 2)$ corresponds to moderate wind, and for $(k \geq 3)$ indicates regular and steady winds (high value of $k$ is indicates more stability in the wind speed) as shown in Figure 5.

The monthly scale parameter which indicats the large value of $(c)$ shows sites with high wind power as presented in Figure 6 . The variation of the monthly wind power density and wind energy intensity at $50 \mathrm{~m}$ high of the selected stations can be seen in Figures 7 and 8 . The results of Figure 9 showed the histogram of the actual wind data and the Weibull probability density function using standard deviation method of annual $k$ and $c$ parameter of the selected stations.

In Figure 10, it can be seen the annual wind rose at stations for the year 2016. The reference direction in wind rose plotted in the East $=0$, North $=90$, West $=180$ and south $=270$. It was found that the main prevailing wind in the Amara region was in the northern direction, about $90 \%$ of the annual wind data was blowing from that direction and $10 \%$ of the wind direction was northwestern. In the Basra station the main prevailing wind was from north-western direction, while in the Al-Hay station the main prevailing wind was north-western direction also. It was the main prevailing wind in Nasiriyah station was western direction, about $60 \%$ of the annual wind data was blowing from that direction and $40 \%$ was north-western.

The wind turbines ATB Riva calzone $(500 \mathrm{kw}, 50 \mathrm{~m}$ hub) and Enercon3 (500kw, 42/48/65m hub high) were selected in this paper as a case study, where, $C_{p}, F$ and $A E P$ per year and cost per $k W h$ was calculated based on the input Weibull parameters $(k, c)$ for the site as shown in Figure 4(b). It can be seen from Table 2, the lowest cost of energy based on the proposed wind turbines in this analysis were found to be $(6.2688,6.6318,7.973$ and $9.6104[\mathrm{c} \$ / \mathrm{kwh}])$ corresponding to the Amara, Basra, Al-Hay and Nasiriyah stations, respectively. It was found that lowest cost of energy when used wind turbine (ATB Riva calzoni) and the costs increased when used Enercon3 wind turbine.

\section{CONCLUSIONS AND REMARKS}

This work presented an accurate analysis of wind characteristics and Weibull wind speed distribution using standard deviation method. In addition to achieve the calculations of $C F$ and $k W h$ generated from wind energy system, the main factors which determined the feasibility of installation of the wind energy system in any proposed site is presented. The selection of the optimum wind turbine for a specific site is considered the main key to obtain the required power at low cost.

The solution of the coupling problem between the site and type of wind turbine is an essential step before starting to install the wind turbines in any country. In this study, four promising sites in the south of Iraq have 
been presented with optimum wind turbine type for these sites. The "WIND ENERGY ANALYSIS" software was introduced in this paper to analyze the wind characteristics and to find the optimum site in Iraq and wind turbine for the optimum site. It was found from the results that the wind turbine (ATB Riva calzone 500kw) was the optimum one for the selected sites. Furthermore, it was found based on the developed software, that the wind rose was dominant in the wind direction which is an important parameter in the installation and construction of the wind turbines.

Table 1. The results of wind analysis tool for (Nasiriyah, Al-Hay, Basra and Amara) stations, 2016.

\begin{tabular}{|c|c|c|c|c|c|c|c|}
\hline Station & $\begin{array}{c}\text { Height } \\
(\mathrm{m})\end{array}$ & $\begin{array}{c}\mathrm{Um} \\
(\mathrm{m} / \mathrm{s})\end{array}$ & $\begin{array}{c}\mathrm{S} . \mathrm{D} \\
(\mathrm{m} / \mathrm{s})\end{array}$ & $\begin{array}{c}\mathrm{K} \\
(-)\end{array}$ & $\begin{array}{c}\mathrm{C} \\
(\mathrm{m} / \mathrm{s})\end{array}$ & WPD $\left(\mathrm{w} / \mathrm{m}^{\wedge} 3\right)$ & WEI $\left(\mathrm{kwh} / \mathrm{m}^{\wedge} 2\right)$ \\
\hline \multirow{3}{*}{ Nasiriyahahyyyyy} & 10 & 2.8544 & 0.99249 & 3.2269 & 3.1855 & 20.3533 & 178.3951 \\
\cline { 2 - 8 } & 30 & 3.2243 & 0.1659 & 3.3544 & 3.5918 & 28.5941 & 250.6188 \\
\cline { 2 - 8 } AL-Hay & 50 & 3.8141 & 0.17948 & 3.53 & 4.2382 & 45.9286 & 402.5379 \\
\hline \multirow{3}{*}{ Basra } & 10 & 2.9233 & 1.2174 & 2.6532 & 3.2825 & 25.4514 & 223.6052 \\
\cline { 2 - 8 } & 30 & 3.295 & 0.24456 & 2.7581 & 3.6961 & 35.2047 & 309.2455 \\
\cline { 2 - 8 } & 50 & 3.8869 & 0.26363 & 2.9025 & 4.3531 & 55.4467 & 486.9568 \\
\cline { 2 - 8 } & 10 & 3.0054 & 1.4348 & 2.2963 & 3.3745 & 30.301 & 265.3181 \\
\hline \multirow{3}{*}{ Amara } & 50 & 3.3809 & 0.33546 & 2.387 & 3.7962 & 41.4907 & 363.3137 \\
\cline { 2 - 8 } & 10 & 3.9783 & 0.35994 & 2.512 & 4.4653 & 64.5347 & 565.1294 \\
\cline { 2 - 8 } & 30 & 3.373 & 0.36065 & 2.2259 & 3.8008 & 46.2474 & 405.5264 \\
\hline
\end{tabular}

Table 2. Wind turbine tool results

\begin{tabular}{|c|c|c|c|c|}
\hline Turbine name & Station & AEP [kwh] per year & CF (\%) & COE [c\$/kwh] \\
\hline \multirow{4}{*}{ ATB Riva calzoni 500kw } & Amara & 478560.86 & 10.9186 & 6.2688 \\
\cline { 2 - 5 } & Basra & 452368.81 & 10.321 & 6.6318 \\
\cline { 2 - 5 } & Al-Hay & 376271.46 & 8.5848 & 7.973 \\
\cline { 2 - 5 } & Nasiriyah & 312160.97 & 7.1221 & 9.6104 \\
\hline \multirow{4}{*}{ Enercon3 500kw } & Amara & 277830.6 & 10.9186 & 10.7979 \\
\cline { 2 - 5 } & Basra & 263729.53 & 6.0171 & 11.3753 \\
\cline { 2 - 5 } & Al-Hay & 222466.93 & 5.0756 & 13.4851 \\
\cline { 2 - 5 } & Nasiriyah & 187917.46 & 4.2874 & 15.9645 \\
\hline
\end{tabular}

Table 3. Wind turbine tool results

\begin{tabular}{|c|c|c|c|c|}
\hline Turbine name & Station & AEP [kwh] per year & CF (\%) & COE [c\$/kwh] \\
\hline \multirow{4}{*}{ ATB Riva calzoni 500kw } & Amara & 478560.86 & 10.9186 & 6.2688 \\
\cline { 2 - 5 } & Basra & 452368.81 & 10.321 & 6.6318 \\
\cline { 2 - 5 } & Al-Hay & 376271.46 & 8.5848 & 7.973 \\
\cline { 2 - 5 } & Nasiriyah & 312160.97 & 7.1221 & 9.6104 \\
\hline \multirow{5}{*}{ Enercon3 500kw } & Amara & 277830.6 & 10.9186 & 10.7979 \\
\cline { 2 - 5 } & Basra & 263729.53 & 6.0171 & 11.3753 \\
\cline { 2 - 5 } & Al-Hay & 222466.93 & 5.0756 & 13.4851 \\
\cline { 2 - 5 } & Nasiriyah & 187917.46 & 4.2874 & 15.9645 \\
\hline
\end{tabular}

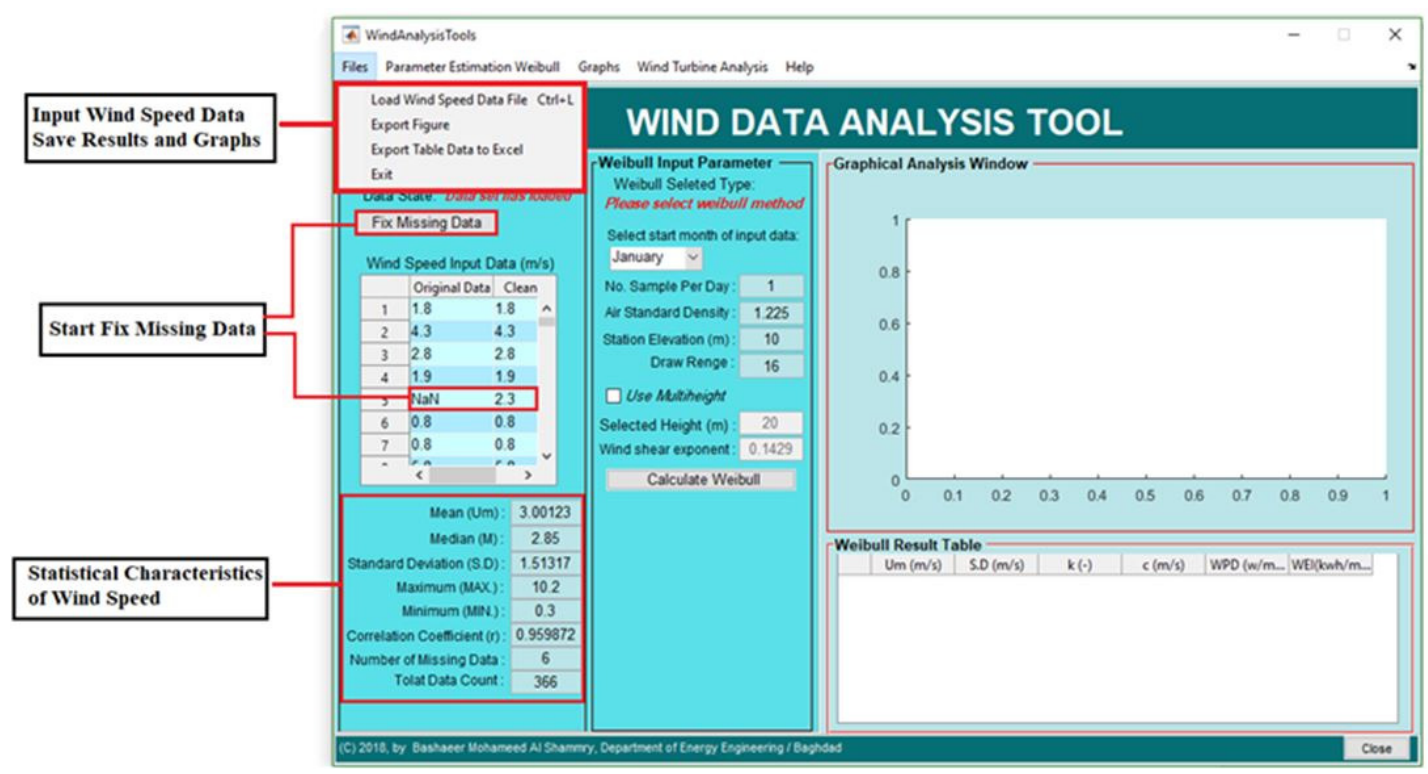

(a). Input data for wind speed and data processing. 


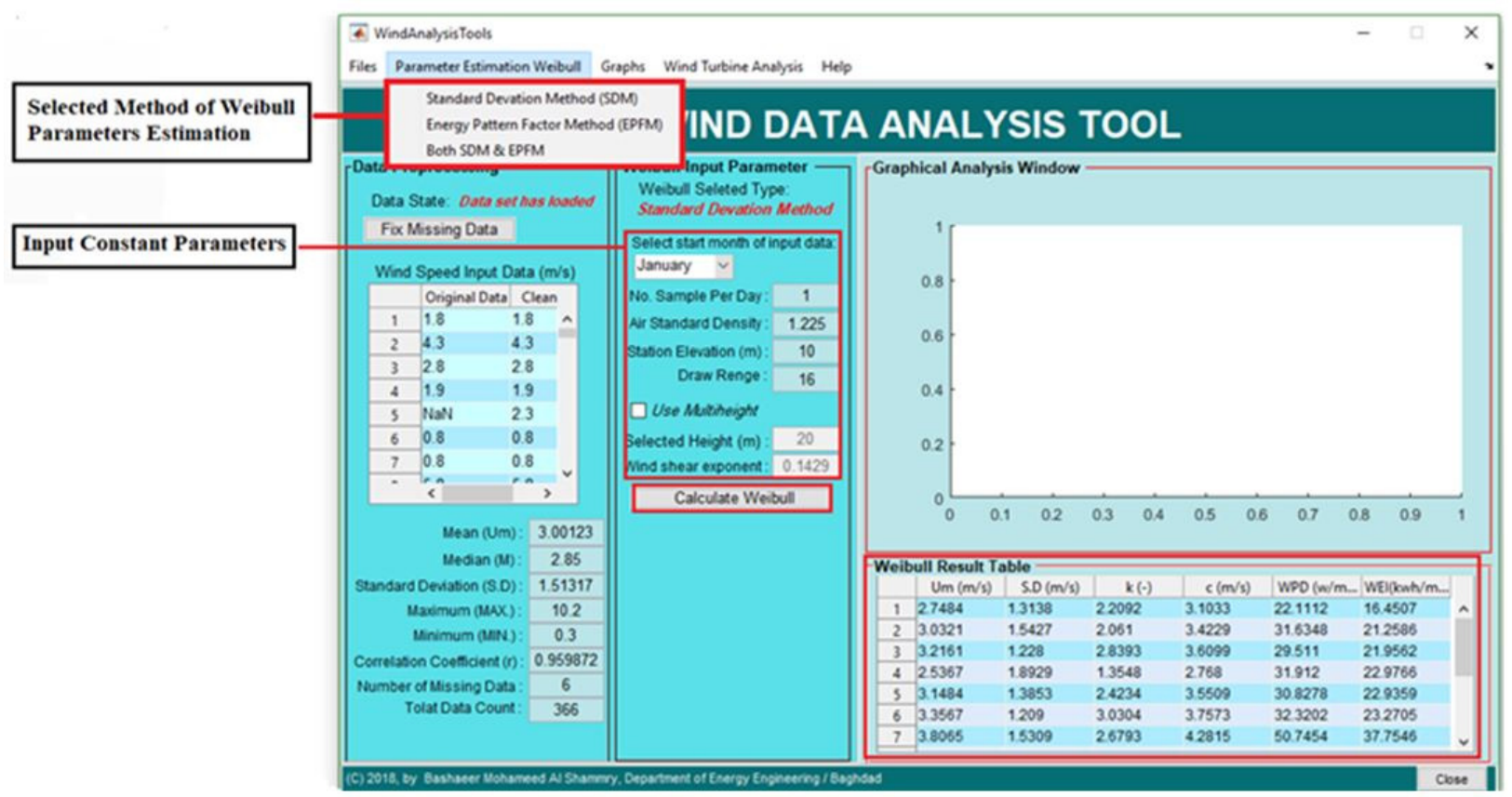

(b). The methods which used in the developed software.

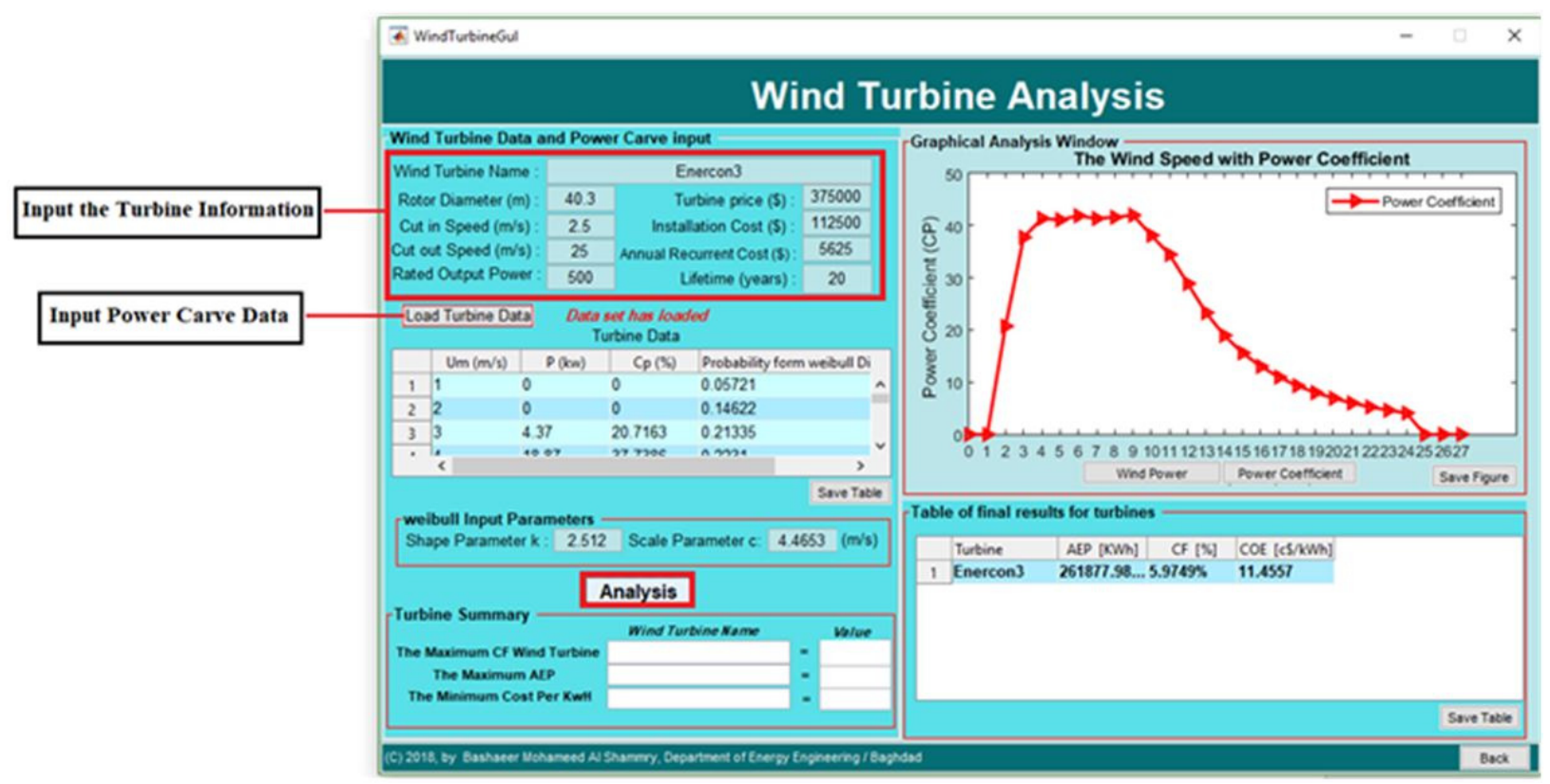

(c). The process to analyze of the wind turbine.

Figure 4. Developed software MATLAB GUI "WIND ENERGY ANALYSIS".

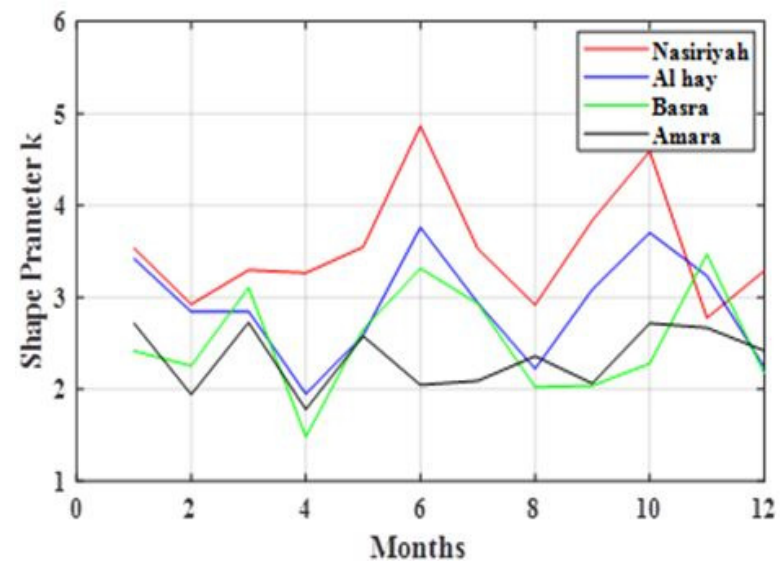

Figure 5. Estimated Weibull parameter $k$ at $50 \mathrm{~m}$ hub high.

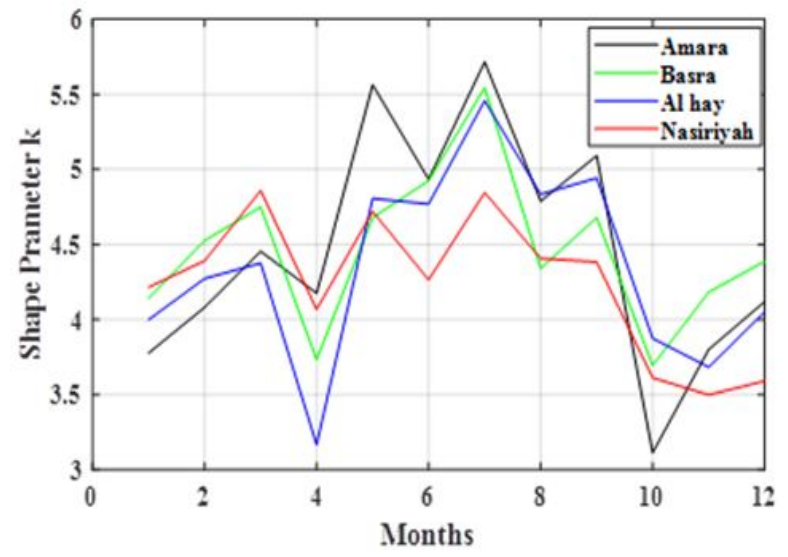

Figure 6. Estimated Weibull parameter $\mathrm{c}(\mathrm{m} / \mathrm{s})$ at $50 \mathrm{~m}$ hub high. 


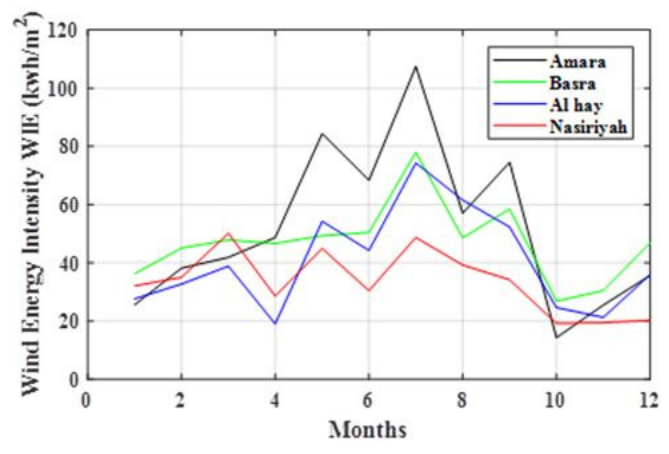

Figure 7. Monthly wind power density at $50 \mathrm{~m}$ hub high.

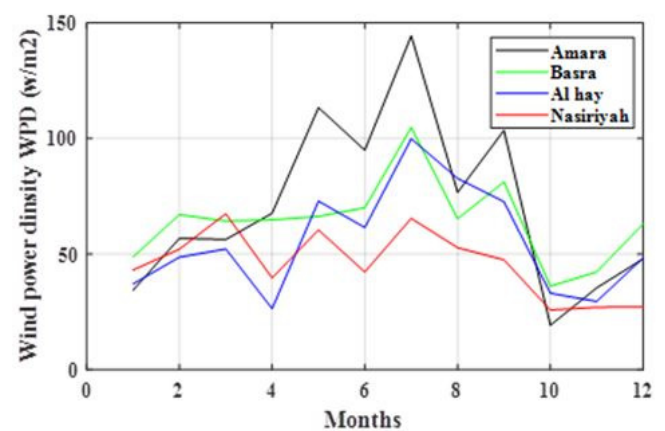

Figure 8. Monthly wind energy intensity at $50 \mathrm{~m}$ hub high.

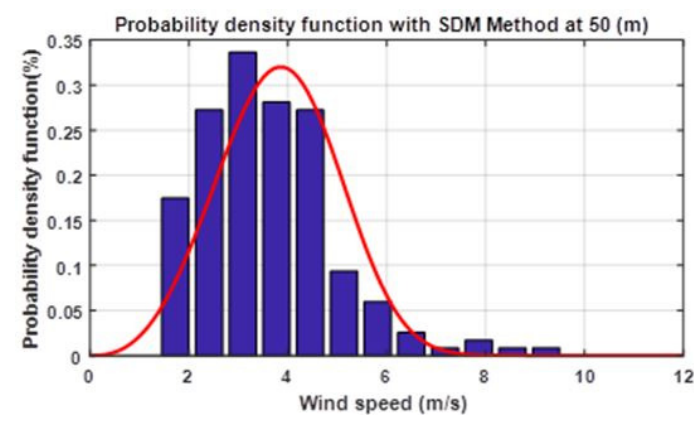

(a) Basra station.

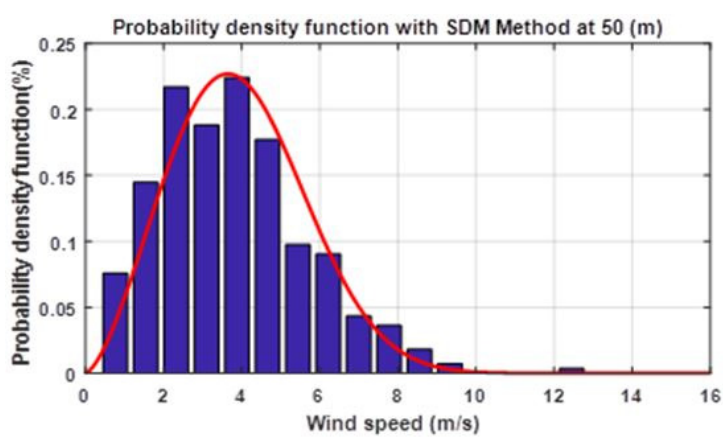

(b) Amara station.

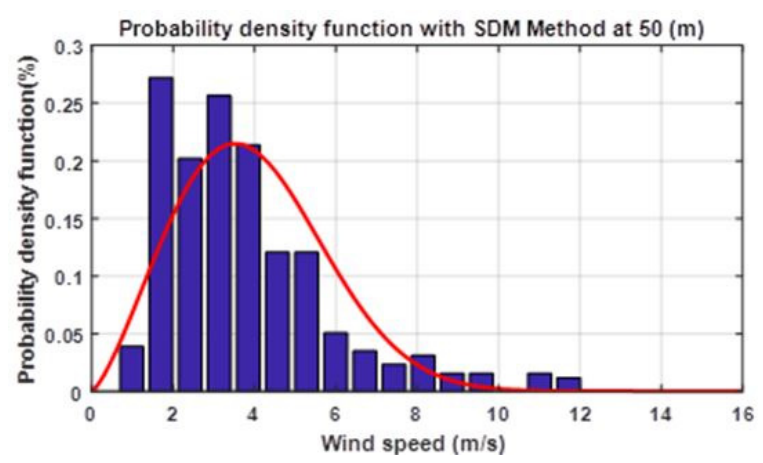

(c) Al hay station.

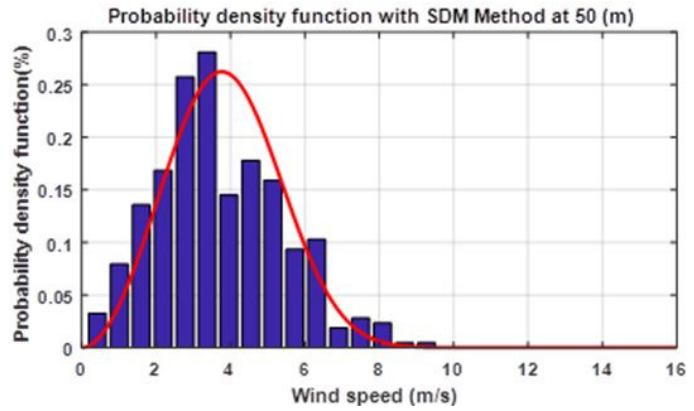

(d) Nasiriyah station.

Figure 9. The histogram of the actual wind data and the Weibull probability density function using standard deviation method of annual $\mathbf{k}$ and $\mathbf{c}$ parameter. [(a)Basra; (b)Amara: (c) Al-Hay and (d) Nasiriyah) stations] 2016.

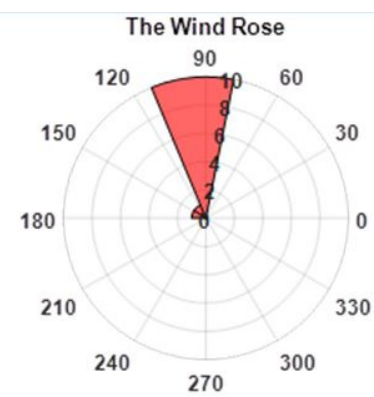

(a) Amara station.

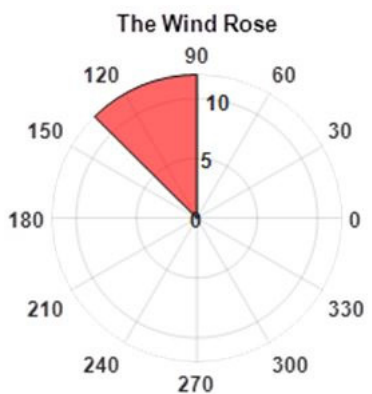

(b) Basra station

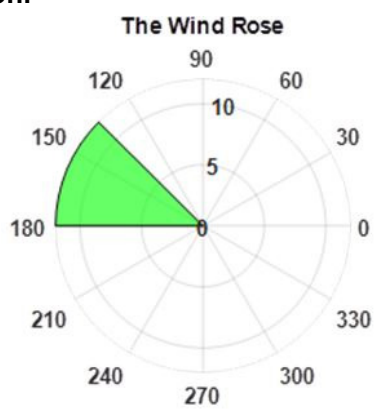

(c) Al-Hay station.

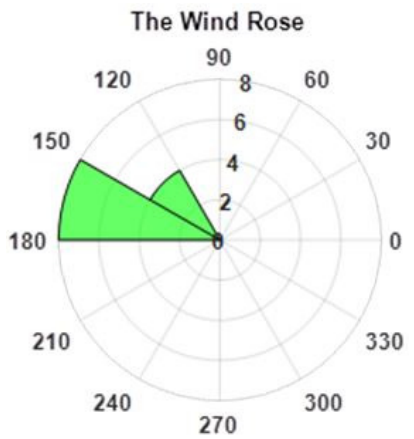

(d) Nsiriyah station.

Figure 10. Annual wind rose in wind direction [(a) Amara; (b) Basra; (c) Al-Hay; and (d) Nasiriyah stations] 2016. 


\section{ACKNOWLEDGEMENTS}

The second affiliation of the second author, Assist. Prof. Dr.-Ing. Oday Ibraheem Abdullah, is Hamburg University of Technology (System Technologies and Engineering Design Methodology), Hamburg- Germany.

\section{REFERENCES}

[1] Parajuli, A.: A Statistical Analysis of Wind Speed and Power Density Based on Weibull and Rayleigh Models of Jumla, Nepal, Energy and Power Engineering, Vol. 8, pp. 271-282, 2016.

[2] Rau, V.G., and Jangamshetti, S.H.: Normalized Power Curves as a Tool for Identification of Optimum WindTurbine Generator Parameters, IEEE Power Engineering Review, Vol. 16, No. 3, pp. 283-8, 2001.

[3] Rehman, SH., and Ahmad, A.: Assessment of wind energy potential for coastal locations of the Kingdom of Saudi Arabia, Energy, Vol. 29, pp. 1105-1115, 2004.

[4] Rocha, P. A. C., Sousa, R. C. d., Andrade, C. F. d., and Silva, M. E. V. d.: Comparison of seven numerical methods for determining Weibull parameters for wind energy generation in the northeast region of Brazil, Applied Energy, Vol. 89, pp. 395-400, 2012.

[5] Jowder, F.A.L.: Wind power analysis and site matching of wind turbine generators in the Kingdom of Bahrain, Applied Energy, Vol. 86, pp. 538-545, 2009.

[6] EL-Shimy, M.: Optimal site matching of wind turbine generator: a Case study of the Gulf of Suez region in Egypt, Renewable Energy, Vol. 35, pp.1870-1878, 2010.

[7] Huang, S. J., Member, S., and Wan, H. H.,: Determination of Suitability between Wind Turbine Generators and Sites Including Power Density and Capacity Factor Considerations, IEEE Transactions on Sustainable Energy, Vol. 3, No. 3, 2012.

[8] Albadi, M. H., and El-Saadany E. F.: Comparative study on impacts of power curve model on capacity factor estimation of pitch-regulated turbines, The Journal of Engineering Research, Vol. 9, No. 2, pp. 36-45, 2012.

[9] Bezrukovs, V., Zacepins, A., Bezrukovs, V. and Komasilovs, V.: Comparison of methods for evaluation of wind turbine power production by the results of wind shear measurements on the Baltic shore of Latvia, Renewable Energy, Vol. 96, pp. 765-774, 2016.

[10] Pelletier, F., Masson, Ch., and Tahan, A.: Wind turbine power curve modeling using artificial neural network, Renewable Energy, Vol. 89, pp. 207-214, 2016.

[11]Xiaoxia, G., Hongxing, Y., and Lin, L.: Optimization of wind turbine layout position in a wind farm using a newly-developed twodimensional wake model, Applied Energy, Vol. 174, pp. 192-200, 2016.
[12] Azooz, A. A., and Talal, S. K.: Evidence of Climate Change in Iraq", Journal of Environment Protection and Sustainable Development, Vol. 1, No. 2, pp. 66-73, 2015.

[13] Al-Azzawi, S. I., and Zaki, N. A.: The wind power potential in Iraq, Majalat Al-buhu, 1987.

[14] Mohammed, A. I.: Estimation Wind Energy in Iraq, Ph.D. Thesis, Almunstansiriyah University, Baghdad, 2007.

[15] Biadgo, M. A., Simonović, A., Komarov, D., and Stupar, S.: Numerical and analytical investigation of vertical axis wind turbine. FME Transactions, Vol. 41, No. 1, pp. 49-58, 2013.

[16] Rašuo, B. P., and Bengin, A. Č.: Optimization of wind farm layout. FME Transactions, Vol. 38, No. 3, pp.107-114, 2010.

[17] Mulugeta, B. A., and Gerawork, A.: Aerodynamic design of horizontal axis wind turbine blades, FME Transactions, Vol. 45, No. 4, pp. 647-660, 2017.

[18] Rasuo, B., Dinulovic, M., Veg, A., Grbovic, A., Bengin, A.: Harmonization of new wind turbine rotor blades development process: A review, Renewable and Sustainable Energy Reviews, Vol. 39, pp. 874-882, 2014.

[19] Rasuo, B., Bengin, A., Veg, A.: On Aerodynamic Optimization of Wind Farm Layout, PAMM, Vol. 10, No. 1, pp. 539-540, 2010.

[20] Mathew, S.. Wind energy: fundamentals, resource analysis and economics (Vol. 1), Berlin: Springer, 2006.

[21] Ulgen, K., and Hepbasli, A.: Determination of Weibull parameters for wind energy analysis of Izmir, Turkey, Int. J. Energy Res., Vol. 26, pp. 495506, 2002.

[22] Karch, H.: Site assessments for wind turbine, Technical Report, School of Science and Engineering, 2016.

[23] Wekesa, D. W., Wang, C., Wei, Y., and Zhu, W.: Experimental and numerical study of turbulence effect on aerodynamic performance of a small-scale vertical axis wind turbine, J. Wind Eng. Ind. Aerodyn., Vol. 157, pp. 1-14, 2016.

[24] Wagner, R., Courtney, M., Gottschall, J., and Marsden, P. L., "Accounting for the speed shear in wind turbine power performance measurement, Wind Energy, Vol. 14, No. 8, 2011.

[25] Oyedepo, S. O., Adaramola, M. S. and Paul, S. S.: Analysis of wind speed data and wind energy potential in three selected locations in south-east Nigeria, International Journal of Energy and Environmental Engineering, Vol. 3, No. 7, 2012.

[26] Wan, Y. H., Ela, E., and Orwig, K.: (2010, June). Development of an equivalent wind plant power curve, in: Proceedings of the Wind Power, 2010, pp. 23-26.

[27] Cooney, C., Byrne, R., Lyons, W., O’Rourke, F.: Performance characterisation of a commercial-scale wind turbine operating in an urban environment, 
using real data, Energy for Sustainable Development, No. 36, pp. 44-54, 2007.

[28] http://www.wind-power-program.com/turbine economics.htm

[29] Holland, O. Thomas, Patrick M.: Graphics and GUIs with MATLAB, Chapman and Hall/CRC, 2002.

\section{NOMENCLATURE}

A Rotor swept area

AEP Annual Energy Production

$C \quad$ Scale parameter $(\mathrm{m} / \mathrm{s})$

$C F \quad$ Capacity factor

cp Power coefficient

$E_{p f} \quad$ Energy pattern factor

$f(U) \quad$ Probability density function

$F(U) \quad$ Cumulative distribution function

$h \quad$ Reference height (m)

$h_{o} \quad$ Hub height (m)

$k \quad$ Shape parameter

$n \quad$ Total number of data

$p \quad$ Wind turbine power

S.D Standard deviation

$T \quad$ Time period (s)

$U_{1} \quad$ Wind speed at a height $\left(\mathrm{z}_{1}\right)(\mathrm{m} / \mathrm{s})$

$U_{2} \quad$ Wind speed at a height $\left(\mathrm{z}_{2}\right)(\mathrm{m} / \mathrm{s})$

$U_{i} \quad$ Wind speed observation at time $\left(\mathrm{i}^{\text {th }}\right)(\mathrm{m} / \mathrm{s})$

Um Mean wind speed $(\mathrm{m} / \mathrm{s})$

WEI Wind Energy Intensity

WPD Wind Power Density $\left(\mathrm{w} / \mathrm{m}^{2}\right)$

$W P D_{W} \quad$ Weibull wind power density

\section{Greek symbols}

$\alpha$ Ground surface friction coefficient, the one-seventh- power law ratio

$\Gamma \quad$ Gamma function

$\rho \quad$ Air density $\left(1.225 \mathrm{~kg} / \mathrm{m}^{3}\right)$

\section{ИСТРАЖИВАЊЕ И АНАЛИЗА ОПТИМАЛНИХ ЛОКАЦИЈА И ПЕРФОРМАНСИ ВЕТРОТУРБИНА У ИРАКУ}

\section{Б. Мохамед, О.И. Абдулах, А.И. Ал-Тмими}

Енергија ветра је један од најзначајних извора обновљиве енергије. Сматра се да је еколошки прихватљива и релативно јефтин извор снаге. Наведене предности су главни разлог за избор ветротурбина за производњу електричне енергије. Прецизна анализа података о ветру сматра се кључним фактором у избору адекватне локације и ветротурбине на основу процена снаге и трошкова. У раду је приказан нови програм базиран на софтверу MATLAB за анализу енергије ветра на одабраним локацијама у Ираку. Кориснички интерфејс GUI је коришћен за презентацију програма „Анализа енергије ветра“. Овај софтвер анализира брзину ветра, обрађује податке који недостају и утврђује коефицијенте корелације, поред уношења резултата анализе (ветар и ружа ветрова). Софтвер приказује комплетне податке о параметрима Вајбулове расподеле применом метода SDM и EPF у циљу селекције оптималне ветротурбине на одређеној локацији у зависности од минималних трошкова по $\mathrm{kWh}$ или максималног капацитета који генерише систем за експлоатацију енергије ветра. 